\title{
Development of milk powder containing Lactobacillus plantarum NCIMB 8826 immobilized with prebiotic hi-maize starch and survival under simulated gastric and intestinal conditions
}

\author{
Ronamae Bradford ${ }^{1}$, Vondel Reyes², Franklin Bonilla², Federico Bueno², Bennett Dzandu², Chen Liu², \\ Alexander Chouljenko ${ }^{2}$ and Subramaniam Sathivel ${ }^{2,3^{*}}$
}

\begin{abstract}
The objectives of this study were to develop a probiotic milk powder containing Lactobacillus plantarum NCIMB 8826 immobilized with prebiotic Hi-maize starch and to analyze cell viability after spray drying and exposure to simulated gastric and intestinal conditions. Milk powders containing free L. plantarum and cells immobilized with $\mathrm{Hi}$-maize starch were assessed. Powders were evaluated during storage at $4^{\circ} \mathrm{C}$ for 15 days. After spray drying, at 0 and 15 days of storage both treatments had over $8 \mathrm{log}$ CFU/g of viable cells and there were higher viable counts found for immobilized cells compared to free cells after $120 \mathrm{~min}$ in simulated gastric fluid. At 15 days of storage, immobilized cells had higher viable counts than free cells after exposure to simulated intestinal fluid for 120 min. The combined probiotic and prebiotic milk powder had stable viable cell counts at refrigerated storage conditions and under simulated gastric and intestinal transit.
\end{abstract}

Keywords: Probiotics, Prebiotics, Simulated gastrointestinal conditions, Milk powder, Spray drying, Immobilization

\section{Introduction}

Probiotics are typically found in raw and fermented milk products such as yogurt, and are known to promote good digestive and immune health. Health benefits associated with probiotic consumption include relief of symptoms of lactose intolerance, diarrhea, treatment of irritable bowel syndrome, cancer suppression, reduction of serum cholesterol, anti-mutagenic and anti-infection properties, improved digestion, and stimulation of gastrointestinal immunity. Consumption of probiotics has been shown to reduce incidences of infectious diseases (Bryce et al. 2005). Lactobacillus plantarum is one species of a commonly used probiotic. It displays

\footnotetext{
* Correspondence: ssathivel@agcenter.Isu.edu

${ }^{2}$ School of Nutrition and Food Sciences, 220 H.D. Wilson Laboratories, Louisiana State University Agricultural Center, Baton Rouge, LA 70803, USA ${ }^{3}$ Department of Biological and Agricultural Engineering, Louisiana State University, Baton Rouge, LA 70803, USA

Full list of author information is available at the end of the article
}

moderate acid tolerance, homofermentative metabolism, and is generally regarded as safe (Brinques \& Ayub 2011). To confer health benefits, at least $10^{7} \mathrm{CFU} / \mathrm{g}$ of the probiotic has to be present in the food. The probiotic should be able to maintain its viability during processing, storage, and gastrointestinal transit in order to colonize the colon (Kailasapathy 2008).

The reduction of probiotics viability subsequent to gastrointestinal transit has prompted researchers to find ways to improve their viability. Immobilization and microencapsulation of probiotics has in recent times been investigated and shown to offer some improvement in bacterial viability after gastrointestinal transit. Immobilization is the process where viable microbial cells are physically confined to a defined region of space in order to limit their free migration while retaining their catalytic activity (Martins et al. 2013). Immobilized cells have exhibited benefits when compared to free cells

(c) The Author(s). 2019 Open Access This article is distributed under the terms of the Creative Commons Attribution 4.0 International License (http://creativecommons.org/licenses/by/4.0/), which permits unrestricted use, distribution, and reproduction in any medium, provided you give appropriate credit to the original author(s) and the source, provide a link to the Creative Commons license, and indicate if changes were made. The Creative Commons Public Domain Dedication waiver (http://creativecommons.org/publicdomain/zero/1.0/) applies to the data made available in this article, unless otherwise stated. 
which include improved process control and protection of cells against damage (Lee \& Heo 2000).

Prebiotics have been gaining popularity as immobilization materials as they are fermentable fibers which are not hydrolyzed in the upper digestive tract, and act as a substrate for the fermentation of probiotics in the colon (Slavin 2013). Hi-maize starch, which is a carbohydrate, can be used to immobilize probiotics. Himaize is a resistant starch that has been shown to behave similarly to fiber, as it is not hydrolyzed in the upper digestive tract (Sajilata et al. 2006). The addition of prebiotics also provides a substrate for the probiotics, fostering an increase in the concentration of these beneficial organisms in the colon. Resistant starches can be used to immobilize probiotics because they support their adherence to the starch granule, which helps to protect the probiotics during processing, storage, and during passage through the upper digestive tract (Anal \& Singh 2007). Spray drying is commonly used in the dairy industry as a low-cost method of producing large amounts of milk powders (Teanpaisan et al. 2012). Spray drying, while economical, can cause thermal inactivation and dehydration of the probiotics owing to the high temperatures used (Anal \& Singh 2007; Corona-Hernandez et al. 2013). Although the exposure time in the spray dryer is very short, the viable bacterial cells can be compromised, resulting in decreased cellular viability after spray drying. The encapsulation material serves to offer protection to the probiotics during spray drying and gastrointestinal transit (Mills et al. 2011).

Extensive research has not been done on the use of Hi-maize starch for the immobilization of probiotics. Immobilization has been utilized in order to develop food products that are able to deliver probiotics for digestive health support. To date, many products have been designed to carry probiotics including fermented and non-fermented dairy products, ice cream, juices, cereals, and cheeses (Yonekura et al. 2014). At present, there are not many powdered milk products on the market that contain both probiotics and prebiotics. While milk is known for its rich and diverse nutritional content, the addition of probiotics may also enhance gut health. In light of this, the aim of this research was to create a powdered milk product containing the probiotic L. plantarum NCIMB 8826 immobilized with Hi-maize starch and to assess its viability after spray drying and under simulated gastric and intestinal conditions.

\section{Materials and methods}

\section{Cell culture preparation}

L. plantarum NCIMB 8826 cells stored in glycerol at $18{ }^{\circ} \mathrm{C}$ were obtained from Louisiana State University's stock collection. De Man, Rogosa, and Sharpe (MRS) broth $(9 \mathrm{~mL})$, obtained from Neogen Corporation,
Lansing, MI, USA, was inoculated with $1 \mathrm{~mL}$ of $L$. plantarum cells and incubated for $24 \mathrm{~h}$ at $37^{\circ} \mathrm{C}$. This preparation was then transferred to $15 \mathrm{~mL}$ MRS broth and incubated for $6 \mathrm{~h}$. After incubation, the contents were transferred to $500 \mathrm{~mL}$ MRS broth and incubated for 16 h. The cells were harvested by centrifuging at 10,000 $\times g$ for $10 \mathrm{~min}$ at $4{ }^{\circ} \mathrm{C}$ using a Sorvall RC28S centrifuge (DuPont, Wilmington, DE, USA). The cells were rinsed twice with sterile distilled water.

\section{Preparation and storage of spray dried milk powder samples}

Two milk samples were prepared using whole milk (Kleinpeter, pasteurized, homogenized, $11 \%$ solids): one containing free $L$. plantarum cells and one containing $L$. plantarum cells immobilized with Hi-maize starch. Concentrated free cell solution was prepared by adding 110 $\mathrm{mL}$ sterile distilled water to rinsed free cells. For the free cell treatment, whole milk $(1 \mathrm{~L})$ was added to the concentrated free cell solution and mixed for $10 \mathrm{~min}$ at $23^{\circ} \mathrm{C}$. For the immobilized cell treatment, a $20 \% \mathrm{Hi}-$ maize starch (Hi-maize 260 resistant starch, Ingredion, Germany) in distilled water mixture was autoclaved at $121^{\circ} \mathrm{C}$ for $15 \mathrm{~min}$ and cooled to $23^{\circ} \mathrm{C}$ before adding $16.5 \mathrm{~g}$ to the concentrated free cell solution, followed by mixing for $30 \mathrm{~min}$. The concentration of Hi-maize was selected based on the results of our preliminary studies (data not shown) conducted to obtain effective immobilization and high viable cell counts. Hi-maize 260 resistant starch is a prebiotic that has been shown to be fermentable by lactobacilli, facilitating their growth (Desai et al. 2004). Whole milk (1 L) was then added and the solution was stirred for $10 \mathrm{~min}$. The samples were spray dried using an Armfield FT80/81 Tall Form Spray Dryer (Armfield Inc., Ringwood, UK) at an inlet temperature of $140^{\circ} \mathrm{C}$, flow rate of $13 \mathrm{~mL} / \mathrm{min}$, and $1 \mathrm{bar}$ air pressure. The powder was collected in a pre-weighed polyethylene bag and the mass of powder was obtained. The drying yield was determined as the percentage of total solids in the liquid feed that were recovered from the collection vessel attached to the cyclone (Barbosa et al. 2016). The powder from each sample was weighed and placed in aluminum bags. These bags were sealed using a Koch Ultravac Sealer (Koch Equipment LLC, Kansas City, MO, USA) at $10 \%$ vacuum. Selected bags from each treatment were stored at $4{ }^{\circ} \mathrm{C}$ for 15 days, while the remaining samples were utilized in subsequent analyses. The powders were stored at $4{ }^{\circ} \mathrm{C}$ because the best survival of probiotics in powders over time has been linked to refrigerated storage (Brinques \& Ayub 2011).

\section{Moisture content and water activity}

The moisture/solids content of the different samples was determined using the CEM Smart System 5 Microwave 
Moisture/Solids Analyzer (CEM Corp., Matthews, NC, USA). The water activity of the powders was determined using an AquaLab water activity meter (Model Series 3 TE, Decagon Devices, Inc., Pullman, WA, USA).

\section{Cell viability}

The viability of the probiotics was assessed by serially diluting the liquid or powder in $0.85 \% \mathrm{NaCl}$ solution. Samples $(100 \mu \mathrm{L})$ from the serial dilutions were placed in petri dishes. MRS agar $(15 \mathrm{~mL})$ containing $0.6 \%$ $\mathrm{CaCO}_{3}$ was poured into each petri dish and swirled to ensure thorough mixing. The plates were incubated at $37^{\circ} \mathrm{C}$ for $48 \mathrm{~h}$ and viable cell counts determined. The results were expressed as $\log \mathrm{CFU} / \mathrm{g}$ sample.

\section{Survival of free and immobilized L. plantarum in milk powder upon exposure to simulated gastric fluid and simulated intestinal fluid}

Simulated gastric fluid (SGF) was prepared according to $\mathrm{Xu}$ et al. (Xu et al. 2016). $\mathrm{NaCl}(1 \mathrm{~g})$ and pepsin (3 g) were dissolved in $250 \mathrm{~mL}$ distilled water, concentrated $\mathrm{HCl}(3.5 \mathrm{~mL})$ was added, and the solution was diluted with distilled water to a final volume of $500 \mathrm{~mL}$. The $\mathrm{pH}$ of the SGF was adjusted to 2.5 with $\mathrm{NaOH}(1 \mathrm{M})$ using a Symphony SB70P pH meter (VWR, Wayne, NJ, USA). Simulated intestinal fluid (SIF) was prepared according to $\mathrm{Xu}$ et al. (Xu et al. 2016). $\mathrm{KH}_{2} \mathrm{PO}_{4}$ (3.4 g) was dissolved in $125 \mathrm{~mL}$ sterile distilled water followed by the addition of $0.2 \mathrm{~N} \mathrm{NaOH}$ solution $(38.5 \mathrm{~mL})$. Sterile distilled water was used to adjust the final volume to 500 $\mathrm{mL}$. Pancreatin powder $(5 \mathrm{~g}, 1 \% \mathrm{w} / \mathrm{v})$ was added and the $\mathrm{pH}$ of SIF adjusted to 6.8. The SGF or SIF was prewarmed to $37^{\circ} \mathrm{C}$ before the powders were added. Milk powder containing free cells ( $1 \mathrm{~g})$ and milk powder containing immobilized cells $(1 \mathrm{~g})$ was added separately to tubes containing SGF or SIF $(9 \mathrm{~mL})$. The tubes were gently shaken and incubated at $37^{\circ} \mathrm{C}$ with agitation (200 rpm). Samples were recovered at 0, 20, 40, 60, and 120 mins and their cell viability was assessed. The survival of L. plantarum was expressed as numbers of viable cells (log CFU/g sample).

\section{Scanning electron microscopy of milk powder samples}

The spray dried milk powders were mounted on aluminum scanning electron microscopy (SEM) stubs and coated in an Edwards S150 sputter coater with gold: palladium (60:40). The coated samples were then observed under a JSM-6610LV scanning electron microscope (JEOL Ltd., Japan).

\section{Statistical analysis}

The results were statistically analyzed using Statistical Analysis System (SAS Version 9.2, SAS Institute Inc., Cary, NC, USA) with data obtained from triplicate experiments for free and immobilized $L$. plantarum on milk powder. To determine differences among treatments, one-way and two-way Analysis of variance (ANOVA) and Tukey's mean separation test were used at a significance level of $\alpha=0.05$.

\section{Results and discussion}

\section{Spray drying yield, water activity, and moisture content} of milk powders

Both milk powder samples had spray drying yields of less than $70 \%(63.0-67.5 \%)$ (Table 1). One study characterized a successful spray drying process as having yields of at least 50\% powder (Can Karaca et al. 2016). A high spray drying yield was characterized as greater than or equal to $85 \%$, which is an acceptable percentage of recovery regardless of the nature of the product. Based on this, it can be said that the milk powders were successfully produced, but had moderate drying yields. Inspection of the spray drying chamber after drying revealed that there was powder attached to the inside of the drying chamber and collection vessel. This could be associated with the presence of sugars, primarily lactose which has a glass transition temperature of $97-116^{\circ} \mathrm{C}$. Spray drying above its glass transition temperature $\left(140^{\circ} \mathrm{C}\right.$ was used in this case) can result in the stickiness of lactose (Abbas et al. 2010). In order to reduce stickiness and increase the glass transition temperature of the feed, a carrier such as maltodextrin can be used. This moderate recovery was largely due to the nature of the product and its processing conditions.

There was no significant difference between the moisture contents of milk powders containing free and immobilized cells. Both treatments had moisture contents of less than $5 \%$, which is what is required for milk powder (Alimentarius 1999). However, there was a significant difference between the water activities of both powders. The milk powder containing immobilized cells had a lower water activity than the free cell powder owing to the addition of Hi-maize starch. Some free water was likely entrapped by the starch in the sample, reducing the water activity. Feeds with higher solids contents tend to dry more rapidly, resulting in a lower water activity compared to low solids feeds. Both samples had

Table 1 Spray drying yield, water activity, and moisture content of milk powders

\begin{tabular}{llll}
\hline Sample & Yield $(\mathrm{g} / 100 \mathrm{~g})$ & Water activity & Moisture $(\mathrm{g} / 100 \mathrm{~g})$ \\
\hline LP-M & $63.0 \pm 12.3^{\mathrm{a}}$ & $0.35 \pm 0.05^{\mathrm{a}}$ & $3.89 \pm 0.50^{\mathrm{a}}$ \\
LP-HM-M & $67.5 \pm 2.0^{\mathrm{a}}$ & $0.31 \pm 0.03^{\mathrm{b}}$ & $3.78 \pm 0.42^{\mathrm{a}}$
\end{tabular}

a,b Means \pm SD with no letter in common within the same column are significantly different $(P<0.05)$. LP-M $=$ milk powder containing free $L$. plantarum NCIMB 8826 and LP-HM-M = milk powder containing L. plantarum NCIMB 8826 immobilized with Hi-maize starch 
a water activity near 0.3 , which would prevent the growth of microorganisms (Patil et al. 2014).

\section{Viability of free and immobilized $L$. plantarum before and after spray drying}

Spray drying, a cost-effective drying method capable of producing large volumes of product, has been shown to sometimes negatively impact cell survival (Corcoran et al. 2004). However, some probiotic strains such as $L$. acidophilus have shown good survival after spray drying $\left(10^{8}-10^{9} \mathrm{CFU} / \mathrm{g}\right)$ (Riveros et al. 2009). Figure 1 illustrates that for both treatments, spray drying did not have an immediate impact on the viability of the L. plantarum cells and no significant difference was seen between both treatments (free LP and immobilized LP) before and after spray drying. There was a reduction of less than 0.3 $\log \mathrm{CFU} / \mathrm{g}$ when comparisons were made within treatments from fresh cells to milk powder. Viable cell counts of greater than $10 \mathrm{log} \mathrm{CFU} / \mathrm{g}$ were achieved, which is more than the $7 \mathrm{log} \mathrm{CFU} / \mathrm{g}$ recommended to confer health benefits.

\section{Survival of free and immobilized L. plantarum cells in milk} powders after exposure to simulated gastric fluid

One negative impact of spray drying is that it can cause the probiotics to become damaged and decrease their ability to withstand stressful conditions (Picot \& Lacroix 2004). This was not evident in the results, as Fig. 2 illustrates that L. plantarum had good overall SGF tolerance. The survival of L. plantarum was analyzed by a two-way ANOVA (cell immobilization $\times$ day of storage). Both cell immobilization $(P<0.05)$, and day of storage $(P<0.05)$, had a significant effect on L. plantarum survival in SGF. The interaction of these main effects was significant indicating that immobilization of $L$. plantarum had different effects through 0 and 15 days of storage $(P<0.05)$. The free cells at 0 days of storage had a significant reduction in viable counts $(0.45 \mathrm{log})$ after exposure to SGF for $120 \mathrm{~min}$. However, the immobilized cells at 0 days of storage only sustained a 0.07 log reduction. After 120 min in SGF, there were no differences in viable counts within respective free or immobilized cell treatments when comparing between 0 and 15 days of storage. While both treatments had adequate survival with greater than $8 \log \mathrm{CFU} / \mathrm{g}$ of cells surviving, the immobilized cells at 0 and 15 days of storage showed significantly higher viable counts than the free cells after exposure to $120 \mathrm{~min}$ of SGF. Hi-maize starch was likely an efficient attachment matrix for L. plantarum cells and may have aided in shielding the cells from unfavorable environmental conditions. Wang et al. (Wang et al. 1999) reported that Bifidobacterium immobilized on high maize resistant starch showed enhanced survival at low $\mathrm{pH}$, bile, and mouse gastrointestinal tract conditions.

\section{Survival of free and immobilized L. plantarum cells in milk powders after exposure to simulated intestinal fluid}

Survival of L. plantarum in SIF was analyzed by a twoway ANOVA (cell immobilization $x$ day of storage). Cell immobilization $(P<0.05)$ and day of storage had $(P<$ $0.05)$ a significant effect on $L$. plantarum survival. Interaction of cell immobilization $\times$ day of storage was significant $(P<0.05)$, showing that immobilization of $L$.

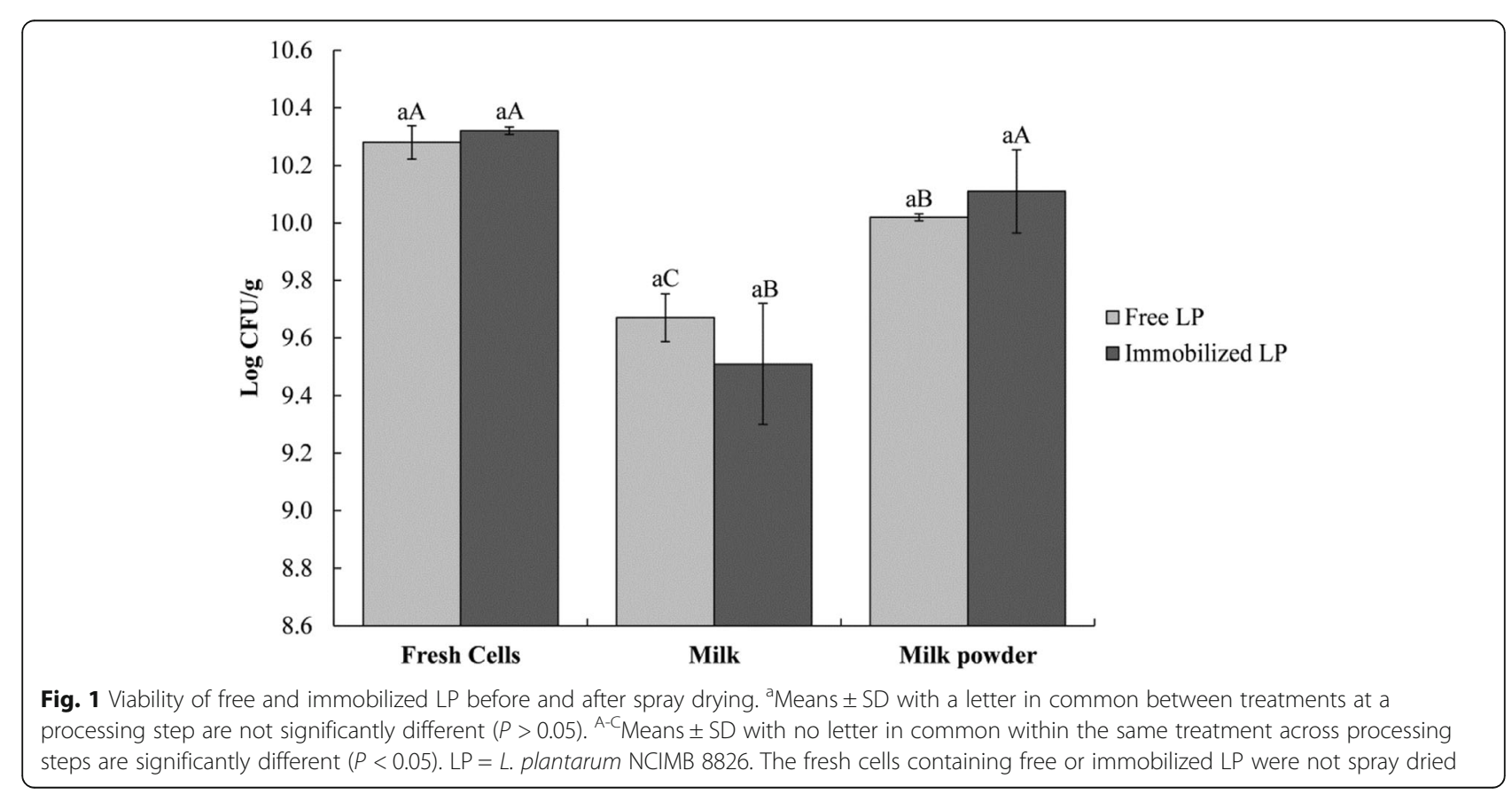




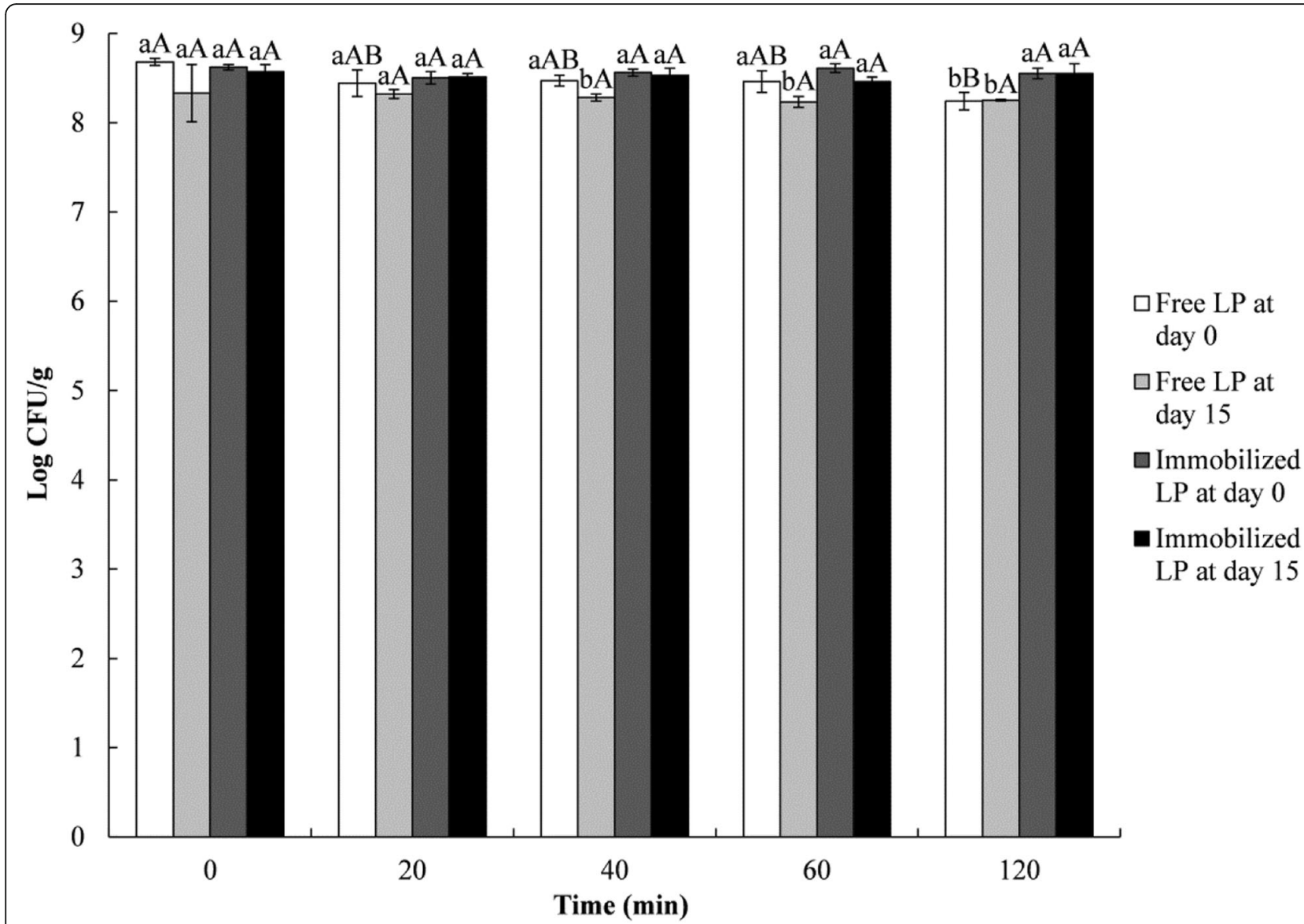

Fig. 2 Survival of LP in stored milk powder during SGF $(\mathrm{pH}=2.5)$ exposure. ${ }^{\mathrm{a}, \mathrm{b}}$ Means \pm SD with no letter in common between treatments at the same SGF exposure time are significantly different $(P<0.05)$. ${ }^{A, B}$ Means \pm SD with no letter in common within the same treatment across SGF exposure times are significantly different $(P<0.05)$. $L P=L$. plantarum NCIMB 8826 and $S G F=$ simulated gastric fluid

plantarum had different effects at 0 and 15 days of storage. Initially and after exposure to SIF for $120 \mathrm{~min}$, the free cells at 0 days of storage had significantly higher viable counts than at 15 days of storage (Fig. 3). In contrast, the viable counts were not different between the immobilized cells at 0 and 15 days of storage. The free cells at 15 days of storage had the lowest cell survival between both treatments. At each storage time, both treatments experienced significant reductions in their respective viable cell counts from 0 to $120 \mathrm{~min}$ in SIF. At 15 days of storage, the immobilized cells survived in significantly higher numbers than the free cells throughout the entire SIF exposure time. The acid and bile conditions which exist in the upper gastrointestinal tract are designed to interfere with the survival of pathogens. Acid exposure can cause damage to proteins and DNA, while bile exposure can impact the integrity of the cell membrane (Mills et al. 2011). When selecting a probiotic, its ability to survive exposure to the harsh conditions which exist in the gastrointestinal system in concentrations greater than $10^{7} \mathrm{CFU} / \mathrm{g}$ is of great importance. L. plantarum appears to have good acid and bile tolerance as the free cells had greater than $8 \log$ $\mathrm{CFU} / \mathrm{g}$ viable cells surviving after exposure to simulated gastric and intestinal conditions. Ability to survive gastrointestinal conditions is strain specific as some bacteria have defense mechanisms which help them to survive in adverse environments. These mechanisms include transporters that regulate decreased $\mathrm{pH}$, chaperone proteins to aid with folding of misfolded proteins, and transport systems which maintain the correct osmolarity (Mills et al. 2011).

\section{Scanning electron microscopy of milk powders}

SEM was used to visualize the morphological properties of both milk powder treatments (Fig. 4). Both powders had shapes that were spherical or oval and did not possess cracks or factures. The milk powder containing cells immobilized with Hi-maize (Fig. 4B, D) had smoother particles compared to milk powder containing free cells (Fig. 4A, C) which had shriveled particles. The milk powder containing immobilized cells likely experienced 


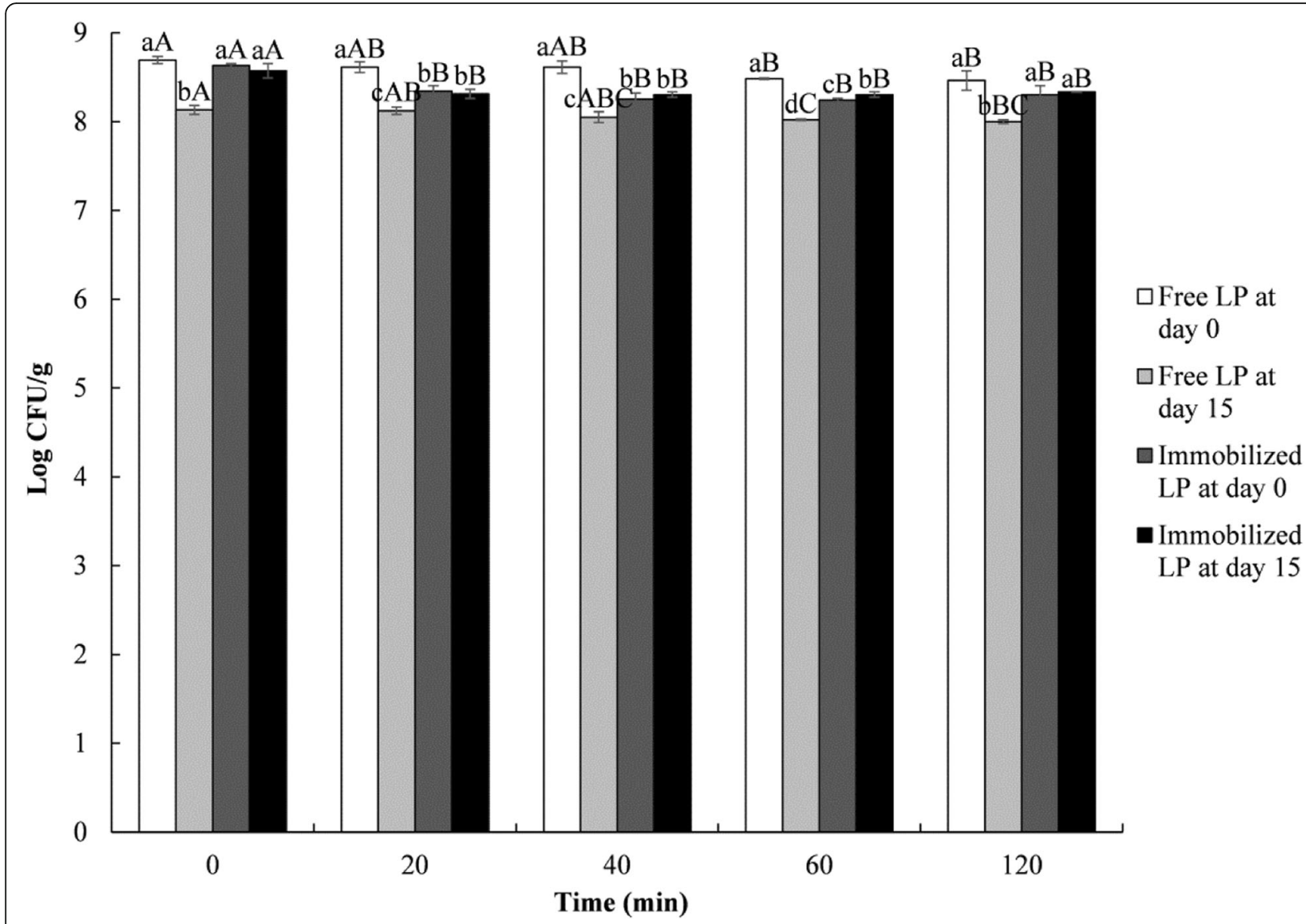

Fig. 3 Survival of LP in stored milk powder during SIF $(\mathrm{pH}=6.8)$ exposure. ${ }^{\mathrm{a}-\mathrm{d}}$ Means \pm SD with no letter in common between treatments at the same SIF exposure time are significantly different $(P<0.05) .{ }^{A-C}$ Means \pm SD with no letter in common within the same treatment across SIF exposure times are significantly different $(P<0.05)$. LP $=$ L. plantarum NCIMB 8826 and SIF = simulated intestinal fluid

a faster drying rate than the free cell powder due to its higher solids content from addition of Hi-maize starch. Dried particles appear shriveled when the drying rate is low. Higher drying rates lead to more rapid moisture evaporation, resulting in a dry and hard skin around the particle. As the particle travels through the dryer and encounters cooler temperatures, its tough formed skin allows it to resist deflation (Tonon et al. 2008).

L. plantarum cells appeared to be fully microencapsulated in the treatment with only free cells and milk and as a result could not be visualized by SEM. However, milk powder samples containing L. plantarum immobilized with Hi-maize had some bacteria attached at the particle surfaces. Martin et al. (Martin et al. 2013) noticed a similar trend with microparticles formed with alginate and starch used to encapsulate L. fermentum. They found that although the particles were smooth and nonporous, probiotic bacteria were present at the surface. Although some bacteria were not encapsulated but merely attached at the particle surface, viable cell counts were stable at over $9 \mathrm{log} \mathrm{CFU} / \mathrm{g}$ during 45 days of storage at $4{ }^{\circ} \mathrm{C}$. In the present study, viable counts between the two powders were not different after spray drying and the immobilized cells exhibited greater SGF and SIF tolerance than free cells. Thus, it is likely that the majority of cells in the immobilized treatment remained encapsulated and were well protected by the solid outer particle surface.

\section{Conclusion}

Milk powder containing L. plantarum cells immobilized on Hi-maize starch was successfully developed and compared to milk powder containing free cells. Both treatments had similarly high cell viability before and after spray drying. SEM micrographs showed that intact microparticles were formed for the free and immobilized cell milk powders. Following exposure to simulated gastric and intestinal conditions, both treatments had greater than $8 \log \mathrm{CFU} / g$ surviving, which is more than the recommended concentration of $10^{7} \mathrm{CFU} / \mathrm{g}$ that should be in the food product to confer health benefits to the consumer. However, immobilization of $L$. 


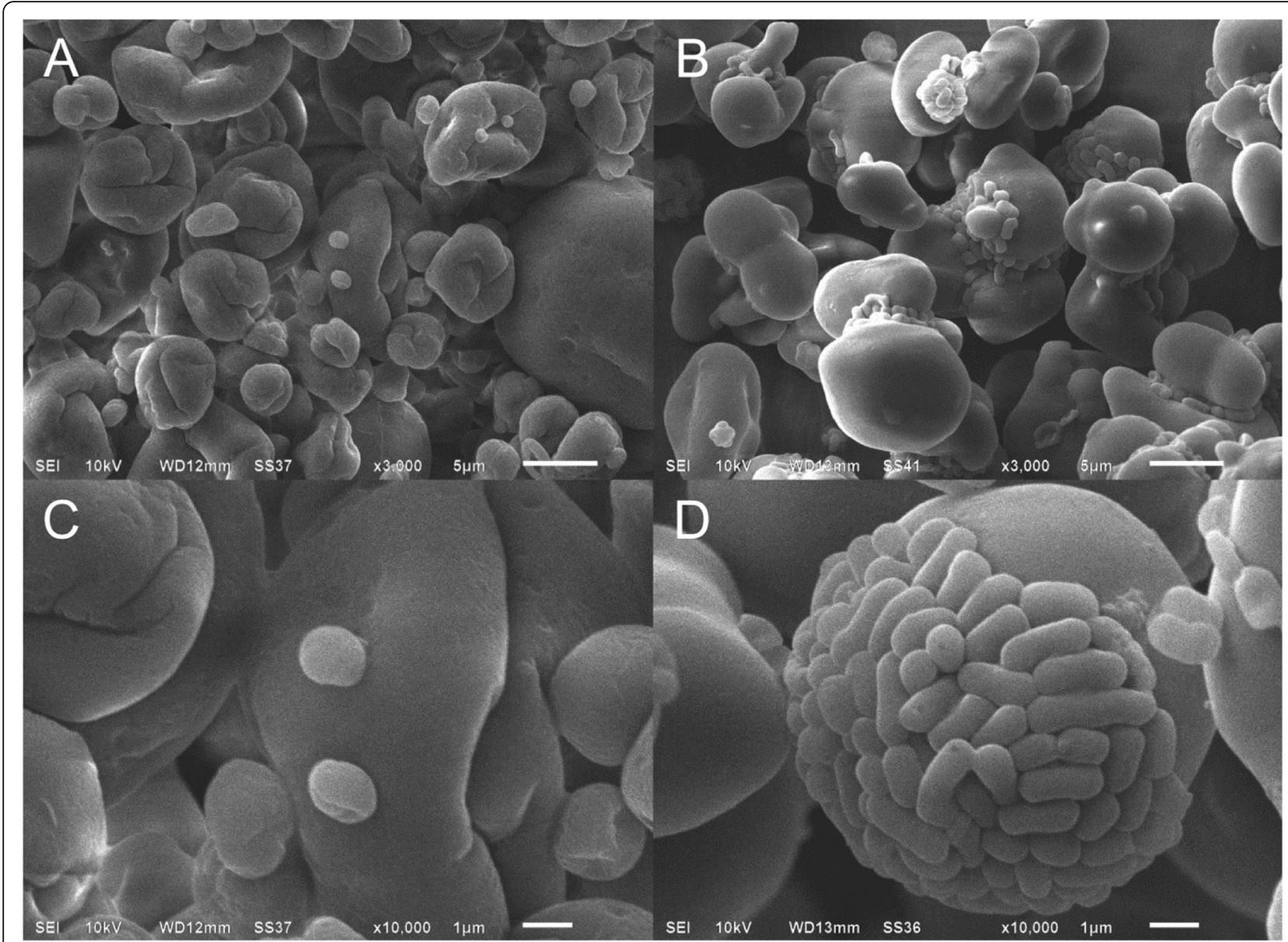

Fig. 4 Scanning electron micrographs of free and immobilized LP in milk powder. a LP-M at 3000x magnification, b LP-HM-M at 3000X magnification, $\mathbf{c}$ LP-M at 10000x magnification, and $\mathbf{d}$ LP-HM-M at 10000x magnification. LP = L. plantarum NCIMB 8826, LP-M = powder containing free LP and milk, and LP-HM-M = powder containing LP immobilized with Hi-maize starch and milk

plantarum with Hi-maize starch improved the survival of viable cells upon exposure to SGF and SIF. Further evaluations can be done to assess the cell viability after exposure to simulated gastrointestinal conditions at various storage conditions with respect to temperature, time, light, packaging, and package atmosphere. This information can be used to develop a marketable combined probiotic and prebiotic milk powder product that may have a better protective system for $L$. plantarum during storage.

\section{Abbreviations}

MRS: De Man, Rogosa, and Sharpe; SEM: Scanning electron microscopy; SGF: Simulated gastric fluid; SIF: Simulated intestinal fluid

\section{Acknowledgements}

Not applicable.

\section{Authors' contributions}

$\mathrm{SS}, \mathrm{RB}$ designed the experiment. $\mathrm{CL}, \mathrm{FBO}, \mathrm{VR}, \mathrm{AC}$, and $\mathrm{BD}$ performed the experiments. FBo analyzed the data. RB, AC, FBu, and SS wrote the article. All authors read and approved the final manuscript.

\section{Funding}

Not applicable.

\section{Availability of data and materials}

All data generated or analyzed during this study are included in this published article. Further details are available from the corresponding author on reasonable request.

\section{Competing interests}

The authors declare that they have no competing interests.

\section{Author details}

'Department of Chemistry, University of the West Indies, Mona, Jamaica. ${ }^{2}$ School of Nutrition and Food Sciences, 220 H.D. Wilson Laboratories, Louisiana State University Agricultural Center, Baton Rouge, LA 70803, USA. ${ }^{3}$ Department of Biological and Agricultural Engineering, Louisiana State University, Baton Rouge, LA 70803, USA.

Received: 1 July 2019 Accepted: 28 October 2019 Published online: 27 November 2019

\section{References}

Abbas, K., Lasekan, O., \& Khalil, S. K. (2010). The significance of glass transition temperature in processing of selected fried food products: A review. Modern Applied Science, 4(5), 3. 
Alimentarius, C. (1999). Codex standard for milk powders and cream powder. Codex Standard., 207.

Anal, A. K., \& Singh, H. (2007). Recent advances in microencapsulation of probiotics for industrial applications and targeted delivery. Trends in Food Science and Technology, 18(5), 240-251.

Barbosa, J., Borges, S., \& Teixeira, P. (2016). Effect of different conditions of growth and storage on the cell counts of two lactic acid bacteria after spray drying in orange juice. Beverages., 2(2), 8.

Brinques, G. B., \& Ayub, M. A. Z. (2011). Effect of microencapsulation on survival of Lactobacillus plantarum in simulated gastrointestinal conditions, refrigeration, and yogurt. Journal of Food Engineering, 103(2), 123-128.

Bryce, J., Boschi-Pinto, C., Shibuya, K., Black, R. E., \& Group WCHER. (2005). WHO estimates of the causes of death in children. The Lancet., 365(9465), 11471152.

Can Karaca, A., Guzel, O., \& Ak, M. M. (2016). Effects of processing conditions and formulation on spray drying of sour cherry juice concentrate. Journal of the Science of Food and Agriculture, 96(2), 449-455.

Corcoran, B., Ross, R., Fitzgerald, G., \& Stanton, C. (2004). Comparative survival of probiotic lactobacilli spray-dried in the presence of prebiotic substances. Journal of Applied Microbiology, 96(5), 1024-1039.

Corona-Hernandez, R. I., Álvarez-Parrilla, E., Lizardi-Mendoza, J., Islas-Rubio, A. R., Rosa, L., \& Wall-Medrano, A. (2013). Structural stability and viability of microencapsulated probiotic bacteria: A review. Comprehensive Reviews in Food Science and Food Safety, 12(6), 614-628.

Desai, A., Powell, I., \& Shah, N. (2004). Survival and activity of probiotic lactobacilli in skim milk containing prebiotics. Journal of Food Science, 69(3), FMS57FMS60.

Kailasapathy, K. (2008). Formulation, administration, and delivery of probiotics. In J. Versalovic \& M. Wilson (Eds.), Therapeutic microbiology: Probiotics and related strategies (pp. 97-118). Washington, DC: ASM Press.

Lee, K.-Y., \& Heo, T.-R. (2000). Survival of Bifidobacterium longum immobilized in calcium alginate beads in simulated gastric juices and bile salt solution. Applied and Environmental Microbiology, 66(2), 869-873.

Martin, M. J., Lara-Villoslada, F., Ruiz, M. A., \& Morales, M. E. (2013). Effect of unmodified starch on viability of alginate-encapsulated Lactobacillus fermentum CECT5716. LWT- Food Science and Technology, 53(2), 480-486.

Martins, S. C. S., Martins, C. M., Fiúza, L. M. C. G., \& Santaella, S. T. (2013). Immobilization of microbial cells: A promising tool for treatment of toxic pollutants in industrial wastewater. African Journal of Biotechnology, 12(28), $4412-4418$

Mills, S., Stanton, C., Fitzgerald, G. F., \& Ross, R. (2011). Enhancing the stress responses of probiotics for a lifestyle from gut to product and back again. Microbial Cell Factories, 10(1), S19.

Patil, V., Chauhan, A. K., \& Singh, S. P. (2014). Influence of spray drying technology on the physical and nutritional properties of guava powder. International Journal of Current Microbiology and Applied Sciences, 3(9), 1224-1237.

Picot, A., \& Lacroix, C. (2004). Encapsulation of bifidobacteria in whey proteinbased microcapsules and survival in simulated gastrointestinal conditions and in yoghurt. International Dairy Journal, 14(6), 505-515.

Riveros, B., Ferrer, J., \& Borquez, R. (2009). Spray drying of a vaginal probiotic strain of Lactobacillus acidophilus. Drying Technology, 27(1), 123-132.

Sajilata, M. G., Singhal, R. S., \& Kulkarni, P. R. (2006). Resistant starch-a review. Comprehensive Reviews in Food Science and Food Safety, 5(1), 1-17.

Slavin, J. (2013). Fiber and prebiotics: Mechanisms and health benefits. Nutrients., 5(4), 1417-1435.

Teanpaisan, R., Chooruk, A., Wannun, A., Wichienchot, S., \& Piwat, S. (2012). Survival rates of human-derived probiotic Lactobacillus paracasei SD1 in milk powder using spray drying. Journal of Science and Technology, 34(3), 247.

Tonon, R. V., Brabet, C., \& Hubinger, M. D. (2008). Influence of process conditions on the physicochemical properties of açai (Euterpe oleraceae Mart.) powder produced by spray drying. Journal of Food Engineering, 88(3), 411-418.

Wang, X., Brown, l., Evans, A., \& Conway, P. (1999). The protective effects of high amylose maize (amylomaize) starch granules on the survival of Bifidobacterium spp. in the mouse intestinal tract. Journal of Applied Microbiology, 87(5), 631-639.

Xu, M., GagXu, M., Gagné-Bourque, F., Dumont, M.-J., \& Jabaji, S. (2016). Encapsulation of Lactobacillus casei ATCC 393 cells and evaluation of their survival after freeze-drying, storage and under gastrointestinal conditions. Journal of Food Engineering, 168, 52-59.

Yonekura, L., Sun, H., Soukoulis, C., \& Fisk, I. (2014). Microencapsulation of Lactobacillus acidophilus NCIMB 701748 in matrices containing soluble fibre by spray drying: Technological characterization, storage stability and survival after in vitro digestion. Journal of Functional Foods, 6, 205-214.

\section{Publisher's Note}

Springer Nature remains neutral with regard to jurisdictional claims in published maps and institutional affiliations.
Ready to submit your research? Choose BMC and benefit from:

- fast, convenient online submission

- thorough peer review by experienced researchers in your field

- rapid publication on acceptance

- support for research data, including large and complex data types

- gold Open Access which fosters wider collaboration and increased citations

- maximum visibility for your research: over $100 \mathrm{M}$ website views per year

At $\mathrm{BMC}$, research is always in progress.

Learn more biomedcentral.com/submissions 